\title{
PERSPEKTYWY ROZWOJU BIOTECHNOLOGII W Polsce
}

\author{
Tadeusz Pietrucha \\ Uniwersytet Medyczny w Lodzi \\ Bio-Tech Consulting sp. z o.o
}

\begin{abstract}
Abstrakt
Ważnym czynnikiem rozwoju biotechnologii w Polsce są nowoczesne badania naukowe. Artykuł Perspektywy rozwoju biotechnologii w Polsce zwraca uwagę na to, że wiedza z zakresu nauk biologicznych i medycznych przyczynia się do większej konkurencyjności zarówno ośrodków naukowych i badawczych, jak i przedsiębiorstw. Biotechnologiczne projekty naukowo-badawcze realizowane $\mathrm{w}$ Polsce nie tworzą jeszcze podstaw do wytwarzania produktów biotechnologicznych w takim zakresie, by polskie przedsiębiorstwa mogły konkurować na rynku międzynarodowych. Jedną z przyczyn, którą analizuje Autor w artykule, jest niewystarczające inwestowanie w rozwój nauki i wsparcie dla małych i średnich firm w sektorze biotechnologii. MSP są najważniejszym elementem rozwoju tego sektora, ponieważ koncentrują się na tworzeniu i rozwoju nowoczesnych produktów biotechnologicznych. Artykuł został podzielony na dwie części: Szanse rozwoju nowoczesnej gospodarki $w$ Polsce bez biotechnologii oraz Edukacja i projekty $B+R$. Autor finalizuje rozważania, pokazując pozytywny scenariusz dla rozwoju sektora biotechnologicznego w Polsce.
\end{abstract}

\section{Wprowadzenie - wiek XXI wiekiem biotechnologii}

„The biotech century" to nie tylko tytuł znanego bestsellera Jeremy'ego Rifkina [1998], ale i dość popularne określenie w literaturze biznesowej XXI wieku. Co powoduje, że biotechnologia jest postrzegana jako główna siła napędowa rozwoju współczesnej gospodarki?

Biotechnologia wychodzi naprzeciw kluczowym potrzebom społeczeństw XXI wieku. Stwarza realne nadzieje na poprawę ochrony zdrowia (leki biotechnologiczne), zapewnienie żywności przy zmniejszających się powierzchniach upraw (żywność i rośliny genetycznie modyfikowane) oraz nowe możliwości pozyskiwania energii odnawialnej.

$\mathrm{W}$ walce $\mathrm{z}$ chorobami cywilizacyjnymi (otyłość, cukrzyca, choroby sercowo-naczyniowe, nowotworowe, Alzheimer) starzejących się 
społeczeństw krajów rozwiniętych coraz większą rolę odgrywają leki biotechnologiczne. Ich liczba systematycznie wzrasta (w roku 2012 dopuszczono do obrotu 39 nowych leków biotechnologicznych). Stanowią one największą grupę wśród leków generujących najwyższe obroty ze sprzedaży (tabela 1).

Tabela 1. Leki biotechnologiczne generujące największą sprzedaż

\begin{tabular}{|l|l|c|c|}
\hline \multicolumn{1}{|c|}{ Lek } & \multicolumn{1}{|c|}{ Firma } & $\begin{array}{c}\text { Sprzedaż w 2010 } \\
\text { r. (mld USD) }\end{array}$ & $\begin{array}{c}\text { Prognozowana sprzedaż w } \\
\text { 2016 r. (mld USD) }\end{array}$ \\
\hline Humira & Abbott, Eisai & 6,7 & 9,7 \\
\hline Avastin & Roche & 6,2 & 7,8 \\
\hline Rituxan & $\begin{array}{l}\text { Roche, Biogen } \\
\text { Idec }\end{array}$ & 6,1 & 7,7 \\
\hline Enbrel & $\begin{array}{l}\text { Amgen, Pfizer, } \\
\text { Takeda }\end{array}$ & 7,3 & 7,1 \\
\hline Herceptin & Roche & 5,2 & 6,5 \\
\hline Remicade & $\begin{array}{l}\text { J\&J, Merck, } \\
\text { Mitsubishi }\end{array}$ & 6,5 & 6,1 \\
\hline Prevnar 13 & Pfizer & 2,4 & 5,8 \\
\hline
\end{tabular}

Źródło: Evaluate Pharma, za G. Steven Burrill (Chief Executive Officer Burrill \& Company), wykład na Bio International Convention, 23.04.2013, Chicago.

Starzejące się społeczeństwa krajów rozwiniętych stanowią coraz większe obciążenie budżetów ochrony zdrowia nawet w przypadku państw stosunkowo bogatych. Według National Cancer Institute szacunkowy roczny koszt generowany przez choroby nowotworowe występujące wśród osób starszych w USA wynosi około 140 mld USD, przez choroby związane z otyłością około $150 \mathrm{mld}$ USD, a przez choroby sercowonaczyniowe około 190 mld USD. Wysokie koszty leczenia chorób cywilizacyjnych związanych $\mathrm{z}$ wiekiem będą praktycznie nie do udźwignięcia $\mathrm{w}$ tych państwach, w których sektor biotechnologii nie będzie dynamicznie rozwijany. Skutki tej sytuacji łatwo sobie wyobrazić - są one już widoczne w krajach o średnich i niskich przychodach, gdzie $80 \%$ zgonów spowodowanych jest chorobami niezakaźnymi (choroby sercowonaczyniowe i nowotworowe).

Kolejnym problemem, z jakim musi zmierzyć się współczesna cywilizacja, jest wzrost zapotrzebowania na żywność przy zmniejszającej się powierzchni uprawnej. W 1965 roku na jednego mieszkańca naszego globu przypadało 0,39 akra ( $1 \mathrm{akr}$ to około $0,4 \mathrm{ha}$ ) powierzchni upraw, w 1985 - 0,29, a w 2005 roku już tylko 0,22 akra. Szacunkowe globalne 
zapotrzebowanie na żywność wynosiło w 2012 roku około 20 gigakalorii, a przewiduje się jego podwojenie do roku 2050.

Efektywność ekonomiczna energii odnawialnej opartej na biomasie z pewnością zależy od klimatu. Jest ona alternatywą dla zmniejszających się zasobów naturalnych, jak również może stanowić przynajmniej częściowe rozwiązanie „problemu” dwutlenku węgla. Rośliny uprawiane do celów przemysłowych akumulują dwutlenek węgla $\mathrm{z}$ powietrza, przetwarzając go na masę organiczną. Niektóre kraje Ameryki Południowej (np. Brazylia) już wykorzystują biopaliwo jako główne źródło energii w transporcie publicznym.

Znaczenie biotechnologii w rozwoju ekonomicznym doceniło już wiele rządów, tworząc specjalne strategiczne programy jej rozwoju. Przykłady takich inicjatyw rządowych zaprezentowane są w tabeli 2.

Tabela 2. Przykłady inicjatyw rządowych wspierających rozwój biotechnologii

\begin{tabular}{|l|l|l|}
\hline \multicolumn{1}{|c|}{ Kraj } & \multicolumn{1}{|c|}{ Program } & \multicolumn{1}{c|}{ Finansowanie } \\
\hline Rosja & $\begin{array}{l}\text { Pharma 2020 } \\
\text { Bio 2020 }\end{array}$ & $\begin{array}{l}12,0 \text { mld USD } \\
39,0 \text { mld USD }\end{array}$ \\
\hline Singapur & $\begin{array}{l}\text { Badania i rozwój, innowacje (brak } \\
\text { wyodrębnionego funduszu dla biotechnologii) }\end{array}$ & 12,9 mld USD \\
\hline Chiny & $12^{\text {th }}$ Five-Year Plan & 1,9 mld USD \\
\hline Tajwan & Biotechnology Take-off Diamont Action Plan & $\begin{array}{l}1,9 \text { mld USD } \\
\text { (Venture Fund) }\end{array}$ \\
\hline Kanada & VC Action Plan & 400,0 mln USD \\
\hline $\begin{array}{l}\text { Korea } \\
\text { Południowa }\end{array}$ & Bio-Vison 2016 & 80 mln USD \\
\hline
\end{tabular}

Źródło: na podstawie danych zaprezentowanych przez G. S. Burrilla (Chief Executive Officer Burrill \& Company) podezas wykładu na Bio International Convention, 23.04.2013, Chicago.

Jak łatwo zauważyć, do rozwoju biotechnologii szczególne znaczenie przykładają kraje rozwijające się, o dużym potencjale wzrostu gospodarczego.

\section{Szanse rozwoju nowoczesnej gospodarki w Polsce bez biotechnologii}

Polska nie dysponuje jak dotąd rządowym programem rozwoju biotechnologii. Co więcej, wiele środowisk opiniotwórczych, uważających się za „postępowe”, wyraża swój głośny sprzeciw np. w stosunku do roślin 
genetycznie modyfikowanych i wytwarzanej na ich bazie żywności. Brak wiedzy przy naiwnie rozpalanej wyobraźni skutkuje w Polsce m.in. znacznym zapóźnieniem technologicznym w tym sektorze.

Jeśli nie będziemy w stanie wytwarzać produktów biotechnologicznych, będziemy musieli je kupować (importować). Nie dysponujemy aż tak dochodowymi sektorami gospodarki, by stać nas było na zakup tych produktów. Nie rozwijając kluczowych działów biotechnologii ( $\mathrm{w}$ tym prac nad roślinami i żywnością genetycznie modyfikowaną), powiększamy swoje uzależnienie od wytwórców i właścicieli nowoczesnych (bio)technologii. W świecie globalnej gospodarki nie da się tworzyć enklaw dobrobytu nieskażonych rozwojem cywilizacji, której współczesnym motorem rozwoju staje się biotechnologia. To nie ona jest zagrożeniem dla współczesnego (polskiego) społeczeństwa - jest nim ignorowanie bądź relatywizowanie tradycyjnych norm moralnych w odniesieniu do biotechnologii.

Biotechnologia powinna być uwzględniona w planie rozwoju nowoczesnej, innowacyjnej gospodarki w Polsce. Rząd powinien wypracować i konsekwentnie realizować strategię jej rozwoju, uwzględniając zarówno zasoby, jak i potrzeby. Bez tego nie dotrzymamy tempa rozwoju narzuconego nie tylko przez kraje o bardziej zaawansowanym rozwoju gospodarczym, ale także przez kraje, które aktualnie przechodzą dynamiczną transformację w kierunku nowoczesnej gospodarki.

W moim przekonaniu, podstawowe cele do osiagnięcia w Polsce w perspektywie roku 2020 to m.in.:

1) zmniejszenie zależności od zagranicznych firm, koncernów dostarczających innowacyjne leki na polski rynek, m.in. poprzez wspieranie rozwoju produkcji leków biopodobnych;

2) rozwój innowacyjności w sektorze biogospodarki, skutkującej przede wszystkim wzrostem liczby firm prowadzących własne projekty badawczo-rozwojowe w celu wytworzenia nowych, innowacyjnych produktów; musimy nauczyć się nie tylko odtwarzać zaawansowane (bio)technologie, ale również je tworzyć, by ta działalność skutkowała zauważalnym polepszeniem sytuacji gospodarczej kraju.

Przyjęcie proponowanej strategii rozwoju biotechnologii skutkować będzie nie tylko poprawą zdrowia obywateli dzięki zwiększonej dostępności do nowoczesnych technologii medycznych, ale również zmniejszeniem zależności ekonomicznej od krajów będących aktualnymi liderami w tworzeniu i rozwoju nowoczesnych (bio)technologii. System ochrony zdrowia w Polsce nie udźwignie kosztów nowoczesnych terapii 
i nie będzie w stanie zapewnić możliwego do osiągnięcia poziomu leczenia, jeśli nie zagwarantujemy rodzimej produkcji nowoczesnych, zaawansowanych technologicznie leków.

Kluczowym elementem rozwoju biotechnologii jest wiedza oparta na nowoczesnych badaniach naukowych, głównie w zakresie nauk biologicznych i medycznych. Jednakże inwestowanie jedynie w rozwój nauki jest w przypadku biotechnologii niewystarczające. Najważniejszym elementem rozwoju tego sektora są małe i średnie firmy, które koncentrują się na tworzeniu i rozwoju nowoczesnych produktów biotechnologicznych. Są to firmy nowego typu, których wartość wycenia się poprzez zgromadzoną $w$ nich wiedzę i umiejętność przetwarzania jej na innowacyjne produkty. Ich cechą jest nie tyle odtwarzanie, ile tworzenie nowych (bio)technologii, produktów poszukiwanych na współczesnym, globalnym rynku. Tego rodzaju firmy są w stanie najlepiej i najefektywniej zagospodarować to, co ciągle jest jeszcze dostępne w zasobach naszego kraju - wykształconych, kreatywnych młodych ludzi, którym współczesny rynek pracy $\mathrm{w}$ Polsce nie jest $\mathrm{w}$ stanie zaoferować atrakcyjnej oferty. Uruchomienie procesu tworzenia tego rodzaju firm oraz zapewnienie im warunków rozwoju jest, moim zdaniem, największym wyzwaniem nie tylko gospodarczym, ale i cywilizacyjnym naszego kraju.

\section{Edukacja i projekty $B+R$}

Studia magisterskie $\mathrm{z}$ biotechnologii (nie licząc kierunków pokrewnych, takich jak np. mikrobiologia, biochemia, biologia molekularna, chemia) kończy rocznie około 1500-2000 studentów [BioTech Consulting, 2012]. Kierunek ten jest obecnie prowadzony na około 30 wyższych uczelniach. Tak dużej liczby absolwentów nie są w stanie wchłonąć polskie firmy biotechnologiczne, których jest aktualnie zaledwie około 80. Część z nich znajduje pracę w firmach farmaceutycznych, których też nie jest zbyt dużo (około 140). Pozostali usiłują znaleźć prace w różnego rodzaju laboratoriach, szkołach lub zmieniają zawód. Najbardziej kreatywni i aktywni, nie mając w kraju perspektywy rozwoju zawodowego, wyjeżdżają za granicę, co bynajmniej nie zawsze oznacza sukces i spełnienie zawodowych marzeń.

W perspektywie nieodległej katastrofy demograficznej istniejący w Polsce kapitał ludzki jest zasobem nie do przecenienia. Jednak, jeśli kiedyś w przyszłości dojrzejemy do tego, by rozwijać biotechnologię, może okazać się, że nie będzie można tego zrobić z powodu braku wystarczającej liczby wykształconych profesjonalistów. 
Duża liczba młodych, wykształconych i pełnych pasji specjalistów stanowi fundament rozwoju nowoczesnej biotechnologii w Polsce. Te zasoby są dostępne tu i teraz - za kilka lat sytuacja może wyglądać już zupełnie inaczej. O tym, jak ważny jest to element rozwoju innowacyjnej gospodarki, świadczy fakt, że w niektórych krajach czynnik ludzki już staje się barierą rozwoju tego sektora gospodarki. W Singapurze, według relacji mojego znajomego, na jedną ofertę pracy $\mathrm{w}$ firmie biotechnologicznej z trudem znajduje się 1-2 kandydatów. Natomiast w Polsce na jedną ofertę pracy w firmie biotechnologicznej (np. Mabion SA) zgłasza się często ponad 200 kandydatów. Dysponując takimi możliwościami wyboru, można stworzyć naprawdę doskonały zespół specjalistów.

W biotechnologii głównym czynnikiem sukcesu są przede wszystkim ludzie. Sukces firmy zależy w znacznie większym stopniu od jakości zespołu tworzonego przez pracowników niż od środków finansowych, jakimi dysponuje firma.

Pomimo niskich nakładów na naukę (realizację projektów badawczorozwojowych), a także pośrednio związanych $\mathrm{z}$ tym stosunkowo niewielkich osiągnięć polskich naukowców w obszarze nauk biologicznych i medycznych, tematyka badawcza będąca podstawą rozwoju współczesnej biotechnologii jest wyraźnie obecna $\mathrm{w}$ polskim środowisku naukowym (rysunek 1).

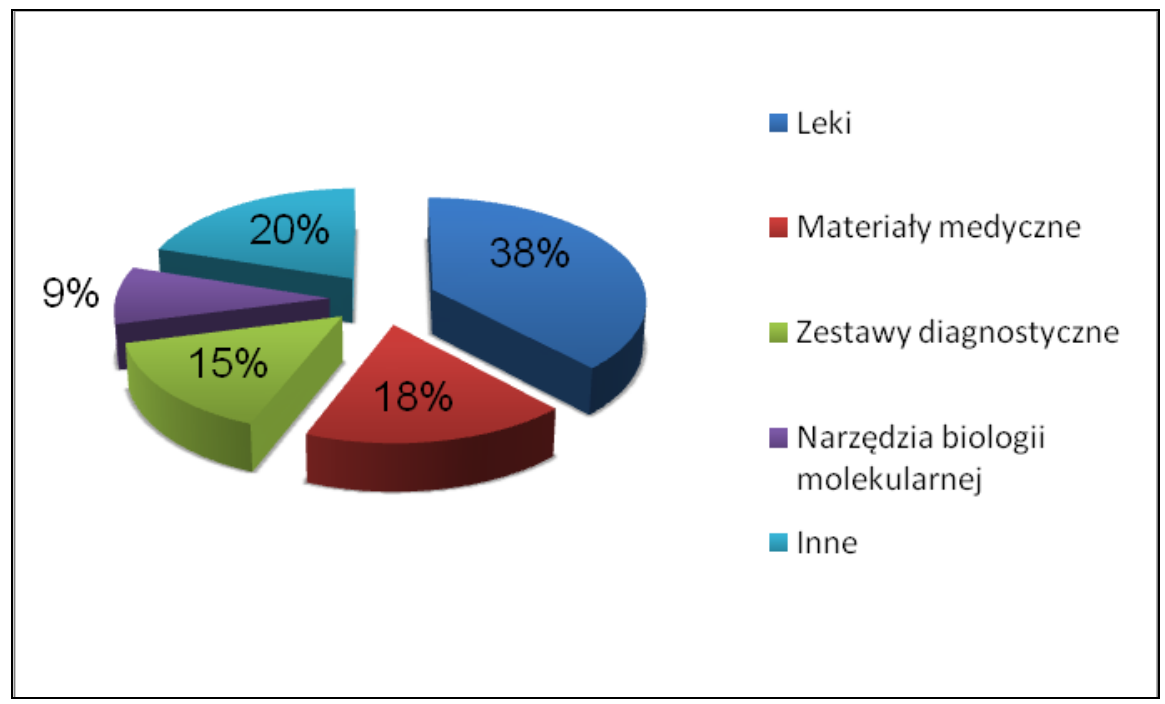

Rysunek 1. Biotechnologiczne projekty badawczo-rozwojowe realizowane w polskich laboratoriach naukowych Źródło: na podstawie danych firmy Bio-Tech Consulting sp. z o.o. 
Zauważyć można powolny, ale jednak wyraźny wzrost zainteresowania realizacją projektów o wyraźnie określonym celu aplikacyjnym. W ciagu ostatnich trzech lat zrealizowano (lub jest jeszcze w trakcie realizacji) około 300 projektów badawczo-rozwojowych w obszarze szeroko rozumianej biotechnologii i nauk przyrodniczych [Bio-Tech Consulting, 2012]. Nawet jeśli zdecydowana większość tych projektów nie osiągnie zamierzonego celu, tzn. nie stanie się rzeczywistym początkiem powstania nowego produktu, to doprowadzenie do przekształcenia nawet niewielkiego procentu projektów w innowacyjne firmy wprowadzi nową jakość do polskiej (bio)gospodarki.

\section{Perspektywy rozwoju - konkluzje}

W perspektywie roku 2020, przy dobrze przemyślanym i konsekwentnie realizowanym narodowym programie rozwoju biotechnologii w Polsce, mogłoby powstać 250-300 nowych innowacyjnych firm biotechnologicznych, tworzących nowe (bio)produkty, wytwarzających nowe (bio)technologie. Jest to liczba, która w mojej ocenie odzwierciedla rzeczywisty potencjał Polski w tym sektorze. Byłby to niesamowity postęp $\mathrm{w}$ stosunku do stanu obecnego. Zrealizowanie tego zadania sytuowałoby polską gospodarkę w zupełnie nowej rzeczywistości, stwarzałoby perspektywy realnej pracy i rozwoju zarówno dla pokolenia młodych, kreatywnych, ambitnych i wykształconych absolwentów wyższych uczelni, jak i zapewniłoby atrakcyjne perspektywy dla osób pobierających obecnie edukację na poziomie szkół średnich. Postawienie takiego celu mogłoby także zmobilizować do powrotu wielu Polaków, którzy zajmują teraz bardzo odpowiedzialne i eksponowane stanowiska w międzynarodowych firmach biotechnologicznych. Ich wiedza i doświadczenie byłyby doskonałym stymulatorem rozwoju tego sektora. Ambitny cel, plan i jego konsekwentna realizacja to najlepszy sposób na uruchomienie niewykorzystanych dotąd należycie pokładów energii i inicjatywy oraz już zgromadzonego kapitału intelektualnego.

To, czy ten optymistyczny scenariusz zostanie zrealizowany, zależy m.in. od tego, czy politycy i społeczeństwo będą w stanie docenić rolę i znaczenie sektora biotechnologii we współczesnej gospodarce. Nie sposób rozwijać go jedynie w oparciu o inicjatywy oddolne, podejmowane przez wąskie grono specjalistów i entuzjastów. W interesie nas wszystkich należy wierzyć, że te perspektywy są realne, a ich realizacja okaże się możliwa. Bez względu na nasze osobiste przekonania i opinie, biotechnologia jest warunkiem rozwoju gospodarczego warunkującego godny poziom życia, 
spełniającego podstawowe standardy rozwiniętego społeczeństwa XXI wieku. Nie sposób przecież zgodzić się na to, by Polska była jedynie atrakcyjnym rynkiem zbytu drogich zazwyczaj produktów biotechnologicznych, sama ich nie wytwarzając. Nie sposób zgodzić się również na rezygnację $\mathrm{z}$ nowoczesnych terapii opartych na lekach biotechnologicznych, których sami nie będziemy w stanie wytworzyć, a przecież przychody $\mathrm{z}$,ekologicznych” produktów nie wystarczą do zapewnienia ich dla osób potrzebujących.

Biotechnologia wchodzi w nasze codzienne życie tak, jak kiedyś weszła motoryzacja, elektronika, informatyka, technologie komunikacyjne. Czy naprawdę stać nas na to, by ten kolejny etap rozwoju technologicznego i cywilizacyjnego odbył się bez naszego aktywnego i świadomego udziału? Jeśli zrezygnujemy $\mathrm{z}$ jego etycznego współtworzenia, nie zapewnimy godnej ekonomicznej egzystencji nie tylko obecnym, ale także i przyszłym pokoleniom.

\title{
Referencje
}

1. Burrill G. S, Evaluate Pharma, wykład na Bio International Convention, 23.04.2013, Chicago 2013

2. Dane prezentowane przez G. S. Burrillana Bio International Convention, 23.04.2013, Chicago 2013

3. Dane firmy Bioconsulting Sp. z o.o., 2012

4. Rifkin J., The Biotech Century, MACLEAN'S, New York 1998, May 4

\begin{abstract}
Biotechnology uses biological processes in the development of technology or manufacture of a product. It is forecasted that Polish biotechnology industry will exceed very quickly. The technology and science parks in Poland have invested millions Euros to build new laboratories. Polish market is fuelled by increased R\&D funding, central and regional governments initiatives. The article on "Polish perspectives of biotechnology development" identifies significant factors for biotechnology project development. It also indicates the examples of government biotechnology initiatives in the world. The author focuses on the statistical analysis of the research and development projects conducted by Polish scientist in scientific laboratories. His main conclusion is that biotechnology will be very important in developing Poland, Polish universities, research and development organizations.
\end{abstract}

